\title{
A Survey of Preservation and Conservation Practices and Techniques in Nigerian University Libraries
}

\author{
By \\ Wole Michael Olatokun, PhD \\ Department of Library and Information Studies, \\ Private Mail Bag 0022, University of Botswana, Gaborone. \\ Email: wole.olatokun@mopipi.ub.bw / woleabbeyolatokun@yahoo.co.uk
}

\begin{abstract}
This study investigated the various techniques used in the preservation and conservation of library materials in selected university libraries in Nigeria. Particularly, it examined the causes and nature of deterioration, patterns and strategies used in their control, existence of preservation and conservation policies and constraints limiting effective preservation and conservation. The survey method was used. Fifteen (15) university libraries were purposively selected. A semi-structured questionnaire was used to collect data. Collected data were structured into grouped frequency distributions using the Statistical Package for the Social Sciences (SPSS) software.

Findings revealed that preservation and conservation techniques, though adopted in the university libraries were not effectively in use although the libraries all have preservation polices. The study also revealed that cleaning and dusting of library materials is the most commonly used technique. The study established that there are indeed incidences of deterioration the most prominent results being books becoming torn and cracking and scratching. Further results showed that though some of the libraries adopt and use some digital preservation techniques, they are still not effectively used. Other findings revealed that inadequate funding was the most severe inhibitor to effective preservation and conservation activities in the university libraries. Based on the findings, recommendations were made towards improving preservation and conservation practices in the libraries.
\end{abstract}

Keywords: Conservation, Library materials, Nigeria, Preservation, Preservation policy, University libraries. 


\section{A Survey of Preservation and Conservation Practices and Techniques in Nigerian University Libraries}

\section{INTRODUCTION AND BACKGROUND}

Among the essential missions of libraries, two are complementary: preservation and access. Preserving for the sake of preserving is useless and giving access lavishly to all documents without taking into account preservation measures will, sooner or later, lead towards making the documentary heritage inaccessible for future generations (Varlamoff, 2005). For decades, librarians have tended to mix up preservation with conservation and all efforts have concentrated on the curative treatment of single documents. Conservation and restoration are the most central activities of preservation; they are concerned with the physical maintenance and repair of documentary materials. According to Roberts and Etherington (nd) (cited in Ngulube, 2003), conservation is a field of knowledge concerned with the coordination and planning for the practical application of the techniques of binding, restoration, paper chemistry, and other material technology, as well as other knowledge pertinent to the preservation of archival resources. Conservation can be further characterized as both preventive and remedial. Preventive conservation consists of indirect action to retard deterioration and prevent damage by creating conditions optimal for the preservation of materials. On the other hand is remedial conservation, which consists mainly of direct action carried out on documents in order to retard further deterioration.

According to the National Library of Australia (2004), one of the major crises facing libraries throughout the world is the rate of deterioration of their collections. Since library materials are composed primarily of organic materials, they are subject to natural deterioration. Most libraries' collections today are based on paper - either in book or sheet form - bound volumes, newspapers, serials, manuscripts, maps, water colours, prints and drawings. Some libraries have an important collection of oil paintings, a small collection of objects, and a large collection of photographic materials including negatives, prints, glass negatives and photographic albums. The collections of modern materials such as sound tapes and electronically stored information such as CD ROMs and computer discs is growing rapidly and almost all of most libraries' collections are essentially impermanent (National Library of Australia, 2004). Unlike museum items that are rarely handled, library materials are meant to be used. They are vital sources of information which cannot be conserved and stored away in an ideal and secure environment to arrest their decay. This is the dilemma of library preservation - to make information accessible, while still ensuring its ultimate survival. As the IFLA-PAC China Centre (2006) puts it: the core activity on preservation and conservation is to ensure that significant library and archive materials, published and unpublished, in all formats, will be preserved in accessible form for as long as possible.

Although an increasing quantity of information is captured at its source in electronic format, a significant percentage of Africa's library and archival documents exist solely in paper form (Katundu 2001; Ngulube, 2002). In fact, until recently, paper was the most common medium available for document creation (Saffady, nd cited in Ngulube, 2003). Even documents created in electronic formats by word processors are usually printed on paper for reference, distribution, or filing. Preserving and conserving these materials has remained one of the greatest challenges faced by African libraries today (Popoola, 2003). Similarly, University libraries in Nigeria today face a lot of problems owing to the deterioration and degradation of their holdings at varying levels. Notably among these problems are that library collections, especially paper-based, are acquired without allocation of adequate resources, (financial and human) to address their future deterioration, lack of proper recognition of the need for preservation, conservation and restoration of information resource. Most library managers fail to realize that preservation and conservation of information resources is a component of the issues they have to contend with. In addition, no training is given to library staff and there is a generally low awareness about preservation issues especially on the corruptible tendencies of information materials and what could be done to prevent their deterioration. In some cases, libraries do not have preservation polices and as a result, there is no preservation plan nor program to ensure safekeeping of library collections. It is against this background that this study was undertaken to survey preservation and conservation techniques and practices in selected university libraries in Nigeria. The specific objectives were to examine the patterns of and strategies for the preservation and conservation of print and non-print library materials, investigate the nature and extent of degradation of library materials, and find out the extent of use of ICT in the preservation and conservation activities of the libraries. It also aimed at identifying the constraints against effective preservation and conservation efforts and find out the existence of preservation and conservation policies in the libraries. The following research questions guided the study:

1. What are the patterns and strategies used in the preservation and conservation of print and non-print library materials in the selected university libraries?

2. What is the nature and extent of degradation of information materials in the selected university libraries? 
What is the degree of information and communication technology (ICT) utilization in the preservation and conservation activities of the selected university libraries?

4. Do preservation and conservation policies exist in the selected university libraries?

5. What are the barriers impeding effective preservation and conservation of information materials in the selected university libraries?

\section{LITERATURE REVIEW}

\section{Preserving digital information}

Digital technology holds great promise for the world's research libraries, for it could revolutionize how we capture, store, preserve, and access information. From the preservation perspective, digital technology offers important reformatting advantages over photocopy and microfilm, including its capability to create a higher quality reproduction of a deteriorating original, the ability to reproduce digital images over and over again with no loss of image quality, greater flexibility in terms of output and distribution, and potential cost savings associated with storage and distribution (Kenney, et al, 2002). Jantz and Giarlo (2005), defined digital preservation as the managed activities necessary for the long term maintenance of a byte stream (including metadata) sufficient to reproduce a suitable facsimile of the original document and for the continued accessibility of the document contents through time and changing technology. Most importantly, digital technology offers unprecedented opportunities for access and use, since it could facilitate the expansion of scholarship by providing timely, distributed access to a variety of sources from a variety of locations Although the advantages of digital technology for preservation reformatting and access enhancement are numerous, there are drawbacks as well. These center on the obsolescence associated with the rapid changes occurring in the development of hardware/software system design, a lack of experience on the part of institutions and service bureaus with digital imaging for preservation, and issues of permanency and standards. Digital technology has the potential to redefine preservation reformatting, but until the concerns associated with maintaining long-term accessibility to material stored in digital image form can be resolved, many libraries and archives are loath to initiate digital projects beyond the pilot phase (Kenney, et al., 2002). With the advent of high-performance computing and high-speed networks, the use of digital technologies is increasing rapidly. Digital technologies enable information to be created, manipulated, disseminated, located, and stored with increasing ease. Ensuring long-term access to the digitally stored information poses a significant challenge, and is increasingly recognized as an important part of digital data management. Digital preservation involves the retention of both the information object and its meaning. It is therefore necessary that preservation techniques be able to understand and re-create the original from or function of the object to ensure its authenticity and accessibility. Recently, several approaches for digital preservation have been identified and presented. Conventional methods are mainly technology emulation, information migration, and encapsulation (Lee, Slattery, Lu, Tang, \& McCarry, 2002).

According to Lee et al, (2002) techniques for the preservation of digital information include technology preservation, preservation emulation, information migration, and encapsulation. Digital resources can be stored on any medium that can represent their binary digits or bits, such as a CD-ROM or a DVD. Rothenberg (1995) (cited in Lee et al, 2002), defines a bit stream as an intended meaningful sequence of bits with no intervening spaces, punctuation, or formatting. To preserve that bit stream, the first requirement is to ensure that the bit stream is stored on a stable medium. If the digital medium deteriorates or becomes obsolete before the digital information has been copied into another medium, the data will be lost. Therefore, digital preservation involves copying the digital information into newer media before the old media becomes obsolete.

\section{Problems of effective preservation and conservation of information materials in Africa}

Information managers in African countries especially librarians, records managers and archivists are currently facing the problem of effective preservation and conservation of information materials in their libraries. Mnjama and Wamukoya (2004) point out that there were real challenges faced by East and Southern Africa member countries in the capture and preservation of records. These include: absence of organisational plans for managing records; low awareness of the role of records management in support of organisational efficiency and accountability; lack of stewardship and coordination in handling records; absence of legislation, policies and procedures to guide the management of records; absence of core competencies in records and archives management; absence of budgets dedicated for records management; poor security and confidentiality controls; lack of records retention and disposal policies; and absence of migration strategies for records. A case study undertaken by Akotia (2000) in the Ministry of Finance in Uganda on the management of financial records in government established that throughout the government of Uganda, ICT was considered an indispensable tool for enhancing productivity. Yet little attention was paid to the information management issues and to understanding the forces of change that affect the form and integrity of the record created within an IT environment. Akotia further noted that the Ministry had no capacity for managing the basic elements of an electronic records programme including: staff who understood the functional requirements for record 
keeping and had the competencies and skills required to manage electronic information delivery systems; legal and administrative requirements for managing electronic records; and accurately documented policies, standard operating procedures and formal methodologies for managing e-records. Popoola (2003) submitted that information professionals in African society today cannot wave aside the obvious fact that the continent stands the imminent risk of losing so much of its valuable documented heritage in consequence of ever increasing deterioration of paper and other media on which they have been stored. He observed that the problems of deterioration are caused by three stakeholders in the African information sector namely: the government, users and the information professionals working in the available information systems. $\mathrm{He}$ recommended that the only antidote to this problem of rapid degradation and decay of information materials is the formulation and implementation of sound preservation and conservation policies and programmes on African information resources.

A survey of literature on preservation and conservation of library materials in Africa revealed that the prominent inhibitors to effective and efficient preservation of information materials in African libraries, archives and record centres include the following:

(i) Inadequate Finance: Almost all African libraries, archives and information centers do not allocate adequate funds in their annual budget for the preservation and conservation of information materials in their holdings. This has really caused the low priority or lack of desired attention given to the preservation and conservation of information resources by the management of such libraries and archives.

(ii) Inadequacy of Equipments/Materials: Lack of suitable or inadequate equipments and materials contributes significantly to the present poor status of preservation and conservation of information materials in African libraries, archives and information centers. Some of the essential materials and equipment required for setting up functional conservation and restoration laboratories in African libraries and archives are not available locally (ESARBICA, 2002).

(iii) Unfavourable Government Economic Policies: The economic policies of most African governments do not favour library and archival services, so preservation and conservation activities are not given the priority attention they deserve. Such economic policies include those concerning high duties and tariffs charged on imports of preservation and conservation equipments

(iv) Tropical Climate: The effects of tropical climate of excessive temperature, high relative humidity, dust, and rodents that feed on paper-based materials cause rapid deterioration and decay of information resources in African libraries and archives. These agents of rapid deterioration and decay of information materials add more to the costs associated with conservation and restoration of information materials in African libraries archives and records offices (UNESCO, 2000). Mwiyeriwa (1998) (cited in Popoola 2003), while stressing the great need for a well established document repair and conservation units in Africa observes that with the exception of air, fungi, insect, and pest are more pronounced in the continent than elsewhere.

(v) Manpower and other infrastructure: For any preservation and conservation programme to succeed in libraries and archives there must be adequate and well-trained manpower (Ngulube, 2001). This is because preservation and conservation of information resources is a specialized field of knowledge that requires information professionals who understand the physical and chemical nature of the materials in their library and archive holdings. Popoola (2003) advocates the need to expose librarians and archivists to conservation and restoration practices during their training. Akussah (1991) (cited in Popoola (2003) suggests that such a training programme should include, operating environmental control, storage and housing, operating environmental systems, designing new buildings or renovation of buildings. Africa has not been able to train students adequately in the area of conservation and restoration of information resources due to lack of functional laboratories where students could undergo practical works. Added to this is the problem of inappropriate buildings, poor power supply and water supply that pose great threat to preservation and conservation of information resources in African countries (Kemoni \& Wamukoya, 2000). Kemoni and Wamukoya (2000) also identified lack of information (IT) skills due to inadequate training as one of the impediments to the management of electronic records at Moi University in Kenya.

(vi) Lack of Preservation and Conservation Policy: Most African countries do not have a national information policy which makes the formulation of preservation and conservation policies in the libraries and information centers out of the question (Wamukoya \& Mutula, 2005). Kemoni (1996) (cited in Popoola (2003), reviewed the conservation programmes of archive materials in Kenya and found that the conservation departments did not have a disaster control plan. The absence of such a plan means that in the event of a disaster, they would not be in a position to respond to the disaster with the urgency that is required.

(vii) Quality of Paper and Ink: The low quality of paper and ink used in the production of information materials especially library book materials and paper-based records in archives and records offices 
pose serious danger to preservation and conservation of information materials in African countries (Popoola, 2003).

\section{RESEARCH METHOD}

The study adopted the survey approach. The population comprised university libraries in Southern Nigeria. Purposive sampling was adopted in selecting the university libraries surveyed owing to pre-study visits that led to the discovery that preservation and conservation practices were not that pronounced in all the southern Nigerian universities. Thus, a total of fifteen university libraries with some level of preservation and conservation practices were purposively selected. Table 1 presents a list of the selected university libraries. The target participants were the librarians, because they were in the best position to give all the necessary information concerning the issues being considered in the study.

Table 1: List of selected universities

\begin{tabular}{|l|}
\hline Federal Universities \\
\hline University of Ibadan, Ibadan \\
\hline Obafemi Awolowo University, Ile-Ife \\
\hline University of Lagos, Lagos \\
\hline University of Benin, Benin \\
\hline University of Port Harcourt, Rivers \\
\hline University of Uyo, Akwa Ibom \\
\hline State Universities \\
\hline River State University of Science and Technology, Port Harcourt \\
\hline Ambrose Alli University, Akpoma, Edo State \\
\hline Olabisi Onabanjo University, Ago-Iwoye \\
\hline Lagos State University, Lagos \\
\hline Delta State University, Abraka \\
\hline Ladoke Akintola University of Technology, Ogbomoso \\
\hline Private Universities \\
\hline Igbinedion University, Okada \\
\hline Lead City University, Ibadan \\
\hline Benson Idahosa University, Benin, Edo State \\
\hline
\end{tabular}

\section{Data Collection and analysis}

Data was collected using a structured questionnaire divided into seven sections (see Figure 1). In order to ensure a high rate of return, copies of the questionnaire were personally administered. The full questionnaire is at Appendix 1.

\section{Figure 1: Structure of the Questionnaire}

Section A: elicited demographic data about the university libraries;

Section B: collected data on the general use of preservation and conservation of library materials;

Section C: asked questions about the patterns and strategies in preserving and conserving print and non-print library materials;

Section D: asked questions on the nature and extent of degradation of library materials;

Section E: elicited data on ICT utilization in preservation and conservation;

Section F: found out the existence of preservation and conservation policy; and

Section G: asked questions on barriers affecting preservation and conservation practices.

All the fifteen (15) copies of the questionnaire administered were returned giving a 100 percent response rate. Responses from the completed questionnaires were coded and analyzed using the Statistical Package for Social Science (SPSS). Descriptive statistics namely frequency, percentage distributions and means were used to present patterns in the data.

\section{RESULTS}

\section{Demographic characteristics of the university libraries}

The results are presented in Figures 2 and 3 . Figure 2 shows that majority or $6(40.0 \%)$ of the university libraries were established before 1980. This is followed by those established between 1980 and 1990. Also, three out of the university libraries were established between 1990 and 2000. The remaining two of the institution libraries were established after 2000. 
Figure 2: $\quad$ Distribution of the university libraries by years of establishment

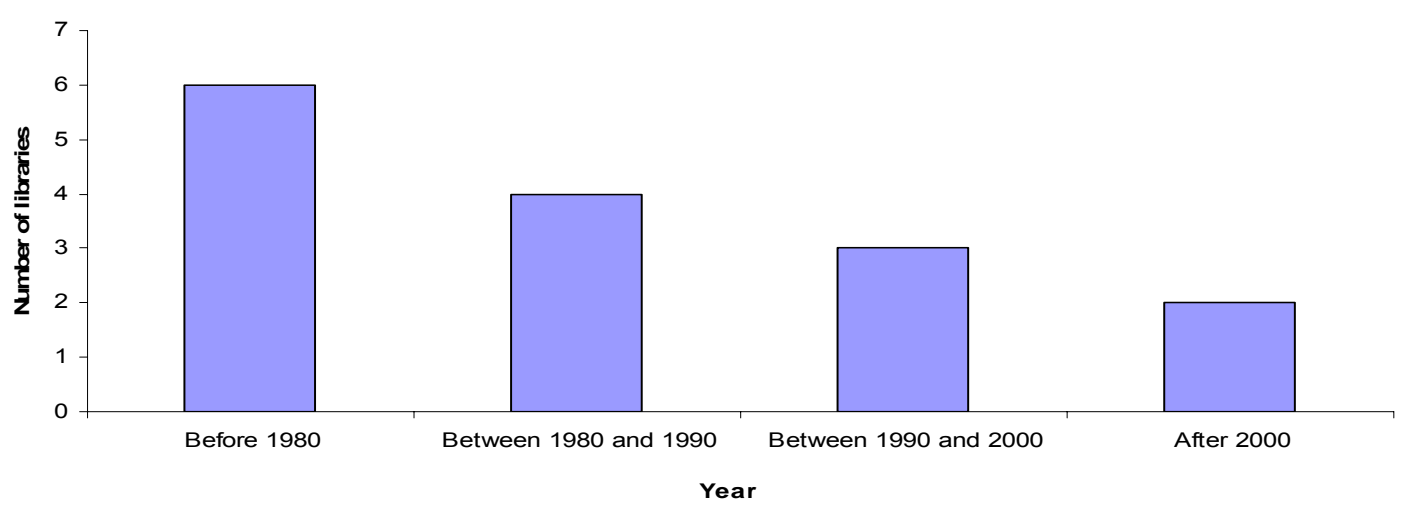

Figure 1: Distribution of university libraries by year of establishment

Figure 3 shows that 40 percent of the libraries are owned by the Federal Government while the same proportion $(40.0 \%)$ is owned by the State Government. Half $(20.0 \%)$ of the federal or state proportion of the university libraries are privately-owned.

Figure 3: Distribution by category of Institution

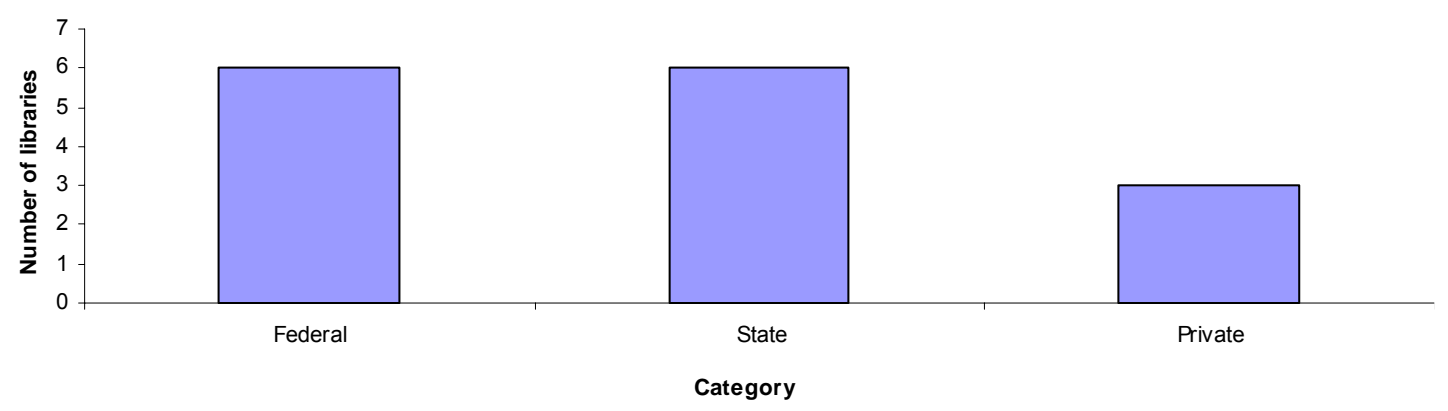

Figure 2: Distribution by category of Institution

\section{Nature and Extent of Degradation of Print and Non-print Library Materials}

Tables 2 and 3 below respectively present the results of the analysis of the nature of degradation of print and non-print library materials in the surveyed university libraries.

Table 2: Nature of Degradation of Print Library Materials

\begin{tabular}{|l|l|l|l|}
\hline $\begin{array}{l}\text { Nature of degradation of print } \\
\text { library Materials }\end{array}$ & $\begin{array}{l}\text { No } \\
\text { extent }\end{array}$ & $\begin{array}{l}\text { Little } \\
\text { extent }\end{array}$ & $\begin{array}{l}\text { Very great } \\
\text { Extent }\end{array}$ \\
\hline Mutilation of library material & $1(6.7)$ & $5(33.3)$ & $9(60.7)$ \\
\hline Vandalization of library material & $3(20.0)$ & $6(40.0)$ & $6(40.0)$ \\
\hline Brittle library materials & $1(6.7)$ & $7(46.7)$ & $7(46.7)$ \\
\hline Broken spine of library material & $0(0.00)$ & $8(53.3)$ & $7(46.7)$ \\
\hline Books becoming torn & $1(6.7)$ & $3(20.0)$ & $11(73.4)$ \\
\hline Others & $14(93.3)$ & $1(6.7)$ & $0(0.00)$ \\
\hline
\end{tabular}

Source: Field survey August 2007

The results show that "books becoming torn" is the highest nature of degradation of print library materials in the surveyed university libraries. This is followed by "mutilation of library materials" while "broken spine of library material" is next. The least nature of degradation of print library materials is "vandalization of library materials". 
Table 3: Nature of Degradation of Non-Print Library Materials

\begin{tabular}{|l|l|l|l|l|r|r|}
\hline Nature of degradation of non-Print Lib Materials & $\begin{array}{l}\text { No } \\
\text { Extent }\end{array}$ & $\begin{array}{l}\text { Little } \\
\text { extent }\end{array}$ & $\begin{array}{l}\text { Moderate } \\
\text { extent }\end{array}$ & $\begin{array}{l}\text { Very great } \\
\text { extent }\end{array}$ & Mean & Std \\
\hline Changing of colour image in photographic materials & $5(33.3)$ & $5(33.3)$ & $3(20.0)$ & $2(13.3)$ & 2.13 & 0.19 \\
\hline Surface blemishes leading to fading & $6(40.0)$ & $3(20.0)$ & $4(26.7)$ & $2(13.3)$ & 2.13 & 0.21 \\
\hline Permanent deformation of sound discs & $6(40.0)$ & $7(46.7)$ & $1(6.7)$ & $1(6.7)$ & 1.80 & 0.14 \\
\hline Fungi on discs surface & $7(46.7)$ & $5(33.3)$ & $2(13.3)$ & $1(6.7)$ & 1.80 & 0.11 \\
\hline Cracking and scratching of sound and optical discs & $4(26.7)$ & $4(26.7)$ & $6(40.0)$ & $1(6.7)$ & 2.27 & 0.11 \\
\hline Poor playback quality of sound discs & $6(40.0)$ & $6(40.0)$ & $2(13.3)$ & $1(6.7)$ & 1.87 & 0.13 \\
\hline Distortion of sound quality on magnetic media & $7(46.7)$ & $5(33.3)$ & $2(13.3)$ & $1(6.7)$ & 1.80 & 0.14 \\
\hline Loss of data on magnetic media & $7(46.7)$ & $5(33.3)$ & $2(13.3)$ & $1(6.7)$ & 1.80 & 0.16 \\
\hline Others & $13(86.7)$ & $0(0.00)$ & $0(0.00)$ & $2(13.3)$ & 0.60 & 0.06 \\
\hline
\end{tabular}

Source: Field survey August 2007

The result shown in Table 3 reveals that highest degradation of non-print materials in the university libraries is "cracking and scratching" (2.27 \pm 0.11$)$ of sound and optical discs followed by "changing of colour image in photographic materials" $(2.13 \pm 0.19)$ and "surface blemishes leading to fading" $(2.13 \pm 0.21)$ is next. The table shows further that "loss of data on magnetic media", "distortion of sound quality on magnetic media", "fungi on disc" and "permanent deformation of sound discs" are the least degradation of non-print materials in the university libraries. This reveals that the highest coefficient value of degradation of non-print materials is cracking and scratching which implies that loss of data on magnetic media, distortion of sound quality on magnetic media, fungi on disc and permanent deformation of sound discs are the least problems facing nonprint materials in the southern university libraries in Nigeria, which means that these libraries still face a little high rate of degradation of library materials.

\section{Causes of Deterioration of Print and Non-Print Materials}

Presented below in Table 4 are the results of the analysis of the various causes of deterioration of print and non-print materials in the surveyed university libraries.

Table 4: Causes of Deterioration of Print and Non-Print Materials

\begin{tabular}{|l|l|l|l|l|l|}
\hline Print Lib Materials & $\begin{array}{l}\text { No } \\
\text { extent }\end{array}$ & $\begin{array}{l}\text { Little } \\
\text { extent }\end{array}$ & $\begin{array}{l}\text { Very great } \\
\text { extent }\end{array}$ & Mean & Std \\
\hline High acidity levels & $4(26.7)$ & $5(33.3)$ & $6(40.0)$ & 2.20 & 0.19 \\
\hline $\begin{array}{l}\text { Wear and tear due to excessive } \\
\text { photocopying }\end{array}$ & $0(0.00)$ & $4(26.7)$ & $11(73.4)$ & 2.87 & 0.16 \\
\hline Air pollution & $4(26.7)$ & $7(46.7)$ & $4(26.7)$ & 2.07 & 0.18 \\
\hline High temperature level & $5(33.3)$ & $5(33.3)$ & $5(33.3)$ & 2.13 & 0.19 \\
\hline Relative humidity & $4(26.7)$ & $7(46.7)$ & $4(26.7)$ & 2.07 & 0.20 \\
\hline Excessive light & $6(40.0)$ & $6(40.0)$ & $3(20.0)$ & 1.87 & 0.15 \\
\hline Dusts and particulate matters & $6(40.0)$ & $3(20.0)$ & $6(40.0)$ & 2.07 & 0.16 \\
\hline $\begin{array}{l}\text { Biological agents (termite, spiders, } \\
\text { cockroaches etc.) }\end{array}$ & $4(26.7)$ & $7(46.7)$ & $4(26.7)$ & 2.07 & 0.19 \\
\hline Bad shelving & $4(26.7)$ & $9(60.0)$ & $2(13.3)$ & 1.87 & 0.14 \\
\hline Others & $13(86.7)$ & $2(13.3)$ & $0(0.00)$ & 1.13 & 0.10 \\
\hline Non-Print Library Materials & & & & & \\
\hline Oxidation & $9(60.0)$ & $4(26.7)$ & $2(13.3)$ & 1.53 & 0.13 \\
\hline Magnetism & $10(66.7)$ & $3(20.0)$ & $2(13.3)$ & 1.47 & 0.13 \\
\hline High humidity and heat & $7(46.7)$ & $4(26.7)$ & $4(26.7)$ & 2.00 & 0.17 \\
\hline Moisture & $7(46.7)$ & $3(20.0)$ & $5(33.3)$ & 2.00 & 0.18 \\
\hline Dust & $3(20.0)$ & $6(40.0)$ & $6(40.0)$ & 2.40 & 0.21 \\
\hline Biological agents (termite, etc.) & $9(60.0)$ & $5(33.3)$ & $1(6.7)$ & 1.47 & 0.13 \\
\hline Atmospheric pollutants & $8(53.3)$ & $6(40.0)$ & $1(6.7)$ & 1.53 & 0.15 \\
\hline Excessive light & $11(73.3)$ & $2(13.3)$ & $2(13.3)$ & 1.47 & 0.11 \\
\hline Others & $14(93.3)$ & $0(0.00)$ & $1(6.7)$ & 0.47 & 0.04 \\
\hline
\end{tabular}

Source: Field survey August 2007

The results displayed in Table 4 show that "wear and tear" $(2.87+0.16)$ is the major cause of deterioration of print materials in the nation's southern university libraries. This is followed by "high acidity level" (2.20+0.19) while "high temperature level" $(2.13+0.19)$ is next. However, the least causes of deterioration of print materials in the nation's southern university libraries are "bad shelving" and "excessive light" with respective mean and standard deviation values of $1.87 \pm 0.14,1.87+0.15$. Also, the major cause of deterioration of non-print materials in the nation's southern university libraries is "dust " $(2.40 \pm 0.21)$ followed by "high humidity" and "heat" $(2.00 \pm 0.17)$ while "moisture" $(2.00 \pm 0.18)$ is next. The least measure of deterioration of non-print 
materials in the nation's southern university libraries are "magnetism" (1.47 \pm 0.13$)$, "biological agents" $(1.47 \pm 0.13)$ and "excessive heat" $(1.47 \pm 0.11)$. This revealed that the least problems facing non-print materials in the southern university library are magnetism, biological agent and excessive heat. While the major cause deterioration is dust due to lack of air-conditions in the selected university libraries.

Preservation and Conservation Techniques of Print and Non-Print Materials in the University Libraries The results of the analysis of the various preservation and conservation techniques in use for print and nonprint materials in the university libraries are presented in Table 5.

Table 5: Preservation and Conservation Techniques of Print \& Non-print materials

\begin{tabular}{|l|l|l|l|l|l|l|}
\hline Preservation and conservation techniques & $\begin{array}{l}\text { No } \\
\text { response }\end{array}$ & Never & Occasionally & Very often & Mean & Std \\
\hline Lamination & $0(0.00)$ & $6(40.0)$ & $6(40.0)$ & $3(20.0)$ & 1.80 & 0.16 \\
\hline Microfilming & $6(40.0)$ & $4(26.7)$ & $4(26.7)$ & $1(6.7)$ & 1.00 & 0.09 \\
\hline Deacidification & $11(73.3)$ & $2(13.3)$ & $1(6.7)$ & $1(6.7)$ & 0.47 & 0.04 \\
\hline Binding & $0(0.00)$ & $0(0.00)$ & $3(20.0)$ & $12(80.0)$ & 2.80 & 0.15 \\
\hline Encapsulation & $8(53.3)$ & $0(0.00)$ & $5(33.3)$ & $2(13.3)$ & 1.07 & 0.10 \\
\hline Cleaning and dusting of library materials & $0(0.00)$ & $0(0.00)$ & $0(0.00)$ & $15(100.0)$ & 3.00 & 0.21 \\
\hline Photocopying & $0(0.00)$ & $0(0.00)$ & $2(13.3)$ & $13(86.7)$ & 2.87 & 0.16 \\
\hline $\begin{array}{l}\text { Shelving library materials to allow for free flow } \\
\text { of air }\end{array}$ & $0(0.00)$ & $1(6.7)$ & $1(6.7)$ & $13(86.7)$ & 2.80 & 0.17 \\
\hline Installing air-conditioners in your library & $0(0.00)$ & $1(6.7)$ & $3(20.0)$ & $11(73.3)$ & 2.67 & 0.13 \\
\hline $\begin{array}{l}\text { Provision of adequate security to prevent theft, } \\
\text { mutilation and defacing of paper-based } \\
\text { materials }\end{array}$ & $0(0.00)$ & $1(6.7)$ & $1(6.7)$ & $13(86.7)$ & 2.80 & 0.18 \\
\hline $\begin{array}{l}\text { Use of insecticide and insect repellant for } \\
\text { library materials preservation }\end{array}$ & $0(0.00)$ & $1(6.7)$ & $10(66.7)$ & $4(26.7)$ & 1.00 & 0.07 \\
\hline Others & $13(86.7)$ & $1(6.7)$ & $0(0.00)$ & $1(6.7)$ & 0.27 & 0.02 \\
\hline
\end{tabular}

Source: Field survey August 2007

The result of the mean and standard deviation of the various parameters in Table 5 show that the most used preservation and conservation technique of print and non-print materials in the university libraries is by "cleaning and dusting" $(3.00 \pm 0.21)$ these materials. This is followed by "photocopying" $(2.87 \pm 0.16)$ the materials to have duplicates while "re-binding" $(2.80 \pm 0.15)$, "shelving library materials to allow for free flow of air" $(2.80 \pm 0.17)$ and "provision of adequate security" $(2.80 \pm 0.18)$ are following. However, the least techniques of preservation and conservation of print and non-print materials are "microfilming" $(1.00 \pm 0.09)$ and the use of "insecticide and insect repellant" $(1.00 \pm 0.07)$. This situation reveals that the most useful strategy used in preserving and conserving print and non-print materials in the university libraries is cleaning and dusting, while the least used is microfilming which implies that though some strategies are being used in preserving and conserving library materials in the libraries, not all the strategies are adopted. 


\section{Duplication for Storage of Non-Print Materials}

Table 6 presents the result of the analysis of the forms of duplication used in the university libraries for storing non-print library materials.

Table 6: Duplication for Storage of Non-Print materials in the University Libraries

\begin{tabular}{|l|l|l|l|}
\hline Storage media & No response & Yes & No \\
\hline Photographic materials & & & \\
\hline Motion picture & $7(46.7)$ & $4(26.7)$ & $4(26.7)$ \\
\hline Film & $10(66.7)$ & $1(6.7)$ & $4(26.7)$ \\
\hline Microforms & $9(60.0)$ & $2(13.3)$ & $4(26.7)$ \\
\hline Optical discs & & & \\
\hline CD-ROM & $8(53.3)$ & $7(46.7)$ & $0(0.00)$ \\
\hline Optical Character Recognition (OCR) & $11(73.3)$ & $1(6.7)$ & $3(20.0)$ \\
\hline Magnetic Ink Character Recognition(MICR) & $11(73.3)$ & $1(6.7)$ & $3(20.0)$ \\
\hline Bar pens & $11(73.3)$ & $1(6.7)$ & $3(20.0)$ \\
\hline Video discs & $6(40.0)$ & $6(40.0)$ & $3(20.0)$ \\
\hline Sound discs & & & \\
\hline Microgroove discs & $10(66.7)$ & $0(0.00)$ & $5(33.3)$ \\
\hline Shellac disks & $10(66.7)$ & $0(0.00)$ & $5(33.3)$ \\
\hline Vinyl discs & $10(66.7)$ & $0(0.00)$ & $5(33.3)$ \\
\hline Magnetic media & & & \\
\hline Cassettes & $9(60.0)$ & $5(33.3)$ & $1(6.7)$ \\
\hline Floppy discs & $6(40.0)$ & $8(53.3)$ & $1(6.7)$ \\
\hline Magnetic tapes & $9(60.0)$ & $3(20.0)$ & $3(20.0)$ \\
\hline Cellulose acetate & $11(73.3)$ & $1(6.7)$ & $3(20.0)$ \\
\hline Mylar & $11(73.3)$ & $1(6.7)$ & $3(20.0)$ \\
\hline
\end{tabular}

Source: Field survey August 2007.

The results in Table 6 reveal that the majority of the surveyed university libraries do not duplicate or have no facility to duplicate photographic materials like motion picture as back-up for storage. This is the same with film and microforms. However, $46.7 \%$ of the libraries have the required facilities and are actually duplicating " $C D$ ROMs" as well as "Video Discs" (40.0\%). All other optical materials like optical character recognizers, "magnetic ink" character recognizers and bar pens are not duplicated due to non-availability of the duplicating devices. Also, none of the libraries indicated that any of the sound discs like microgroove discs, shellac disks and vinyl discs is duplicated for back-up storage. However, five and eight of the fifteen libraries use cassettes and floppy discs as back-ups. Result shows further that "cellulose acetate" and "mylar" are not being used for duplicating in the university libraries implying that most of them do not duplicate or do not have some of the storage media facilities for duplicating.

\section{Utilization of Digital Preservation Techniques in the University Libraries}

The result of the analysis of the use and frequency of use of digital preservation techniques in the university libraries is presented in Table 7.

Table 7: Utilization of digital preservation techniques

\begin{tabular}{|l|l|l|l|l|l|l|}
\hline Digital Preservation techniques & $\begin{array}{l}\text { No } \\
\text { response }\end{array}$ & Never & Occasionally & $\begin{array}{l}\text { Very } \\
\text { often }\end{array}$ & Mean & Std \\
\hline Refreshing & $4(26.7)$ & $1(6.7)$ & $8(53.3)$ & $2(13.3)$ & 1.53 & 0.12 \\
\hline Technology preservation & $6(40.0)$ & $1(6.7)$ & $6(40.0)$ & $2(13.3)$ & 1.27 & 0.11 \\
\hline $\begin{array}{l}\text { Migration (transfer of digital materials from one } \\
\text { generation of computer technology to a subsequent } \\
\text { generation) }\end{array}$ & $6(40.0)$ & $2(13.3)$ & $4(26.7)$ & $3(20.0)$ & 1.27 & 0.12 \\
\hline Emulation (preserving the original application program) & $8(53.3)$ & $2(13.3)$ & $5(33.3)$ & $0(0.00)$ & 0.80 & 0.05 \\
\hline Encapsulation & $7(46.7)$ & $1(6.7)$ & $7(46.7)$ & $0(0.00)$ & 1.00 & 0.06 \\
\hline Microfilming & $10(66.7)$ & $4(26.7)$ & $1(6.7)$ & $0(0.00)$ & 0.40 & 0.01 \\
\hline None of the above & $13(86.7)$ & $2(13.3)$ & $0(0.00)$ & $0(0.00)$ & 0.13 & 0.01 \\
\hline
\end{tabular}

Source: Field survey August 2007

The data in Table 7 show that the major use of digital preservation technique in the university libraries is "refreshing" with a mean value of 1.53 . Though, this is occasionally used by only 53.3 percent of the libraries while 13.3 percent of the libraries use it very often. This is followed by "technology preservation" (1.27) which is occasionally used by 40.0 percent of the libraries while only 13.3 percent use it very often. "Migration" (1.27) is also used by the libraries although it is used by 26.7 and 20.0 percents of the libraries occasionally and very often respectively. Result shows further that "microfilming" (0.40), "emulation" (0.80) and "encapsulation" (1.00) are seldom used by the libraries. The highest coefficient value of digital preservation technique used is 
refreshing and it's a little above average, while the other variables are below 30 percent, which implies that digital preservation is not widespread in use in the selected university libraries while some do not even practise it at all.

\section{Policy and other preservation issues in the University Libraries}

Table 8 presents the results of the analysis of the existence of preservation policy, the content of such policies as well as other preservation issues in the university libraries.

Table 8: Policy and other preservation issues in the university libraries

\begin{tabular}{|c|c|c|c|}
\hline Print Library Materials & Yes & No & No resp. \\
\hline Do you use preservation and conservation techniques in your library? & $15(100.0)$ & $0(0.00)$ & $0(0.00)$ \\
\hline $\begin{array}{l}\text { Are the information in your non-print materials transferred to other } \\
\text { storage media for duplication? }\end{array}$ & $7(46.7)$ & $6(40.0)$ & $2(13.3)$ \\
\hline Does your library have digital resources in its collections? & $12(80.0)$ & $2(13.3)$ & $1(6.7)$ \\
\hline Does your library train staff on preservation of library materials? & $10(66.7)$ & $3(20.0)$ & $2(13.3)$ \\
\hline \multicolumn{4}{|l|}{ Policy Issues in the Library } \\
\hline Does your library have a preservation policy? & 12(80.0) & $3(20.0)$ & $0(0.00)$ \\
\hline Is the preservation policy adhered to in your library? & $12(80.0)$ & $2(13.3)$ & $1(6.7)$ \\
\hline $\begin{array}{l}\text { Has the policy provided direction to library staff in carrying out their } \\
\text { collection management responsibilities relating to preservation? }\end{array}$ & $12(80.0)$ & $1(6.7)$ & $2(13.3)$ \\
\hline Does the policy provided guidelines on security of library materials? & 14(93.3) & $0(0.00)$ & $1(6.7)$ \\
\hline Does the policy provided guidelines on use of library materials? & $14(93.3)$ & $0(0.00)$ & $1(6.7)$ \\
\hline Does the policy addresses disaster recovery procedure? & $9(60.0)$ & $3(20.0)$ & $3(20.0)$ \\
\hline Has the policy impacted positively on the handling of library materials? & $13(86.7)$ & $0(0.00)$ & $2(13.3)$ \\
\hline $\begin{array}{l}\text { Does the policy has guidelines on restoration of degraded library } \\
\text { materials? }\end{array}$ & $9(60.0)$ & $3(20.0)$ & $3(20.0)$ \\
\hline Has the policy enhanced preservation positively? & $9(60.0)$ & 1(6.7) & $5(33.3)$ \\
\hline
\end{tabular}
Source: Field survey August 2007

The results presented in Table 8 show that all (100.0\%) the surveyed university libraries have preservation and conservation techniques. However, only 46.7 percent of them have the information in their non-print materials transferred to other storage media while majority or $12(80.8 \%)$ have digital resources in their collection. Similarly, $12(80.0 \%)$ of them have preservation policy which is expected to enhance their library operations provided its provisions are adhered to and implemented. Results also show that $12(80.0 \%)$ of them indicated that these policies have provided direction to library staff in carrying out their collection management responsibilities relating to preservation of security of library material as informed by 93.3 percent of the libraries while 60.0 percent informed that the policy has helped in disaster recovery procedure. Also, 66.7 percent of the libraries are of the opinion that the policies have helped in handling their library materials. Results in Table 8 reveal further that training of staff on preservation of library materials have been enhanced (66.7\%) while 60.0 percent of the libraries are of the opinion that restoration of degraded library materials have been enhanced by the policies. In general, 60.0 percent of the university libraries agreed that the policy has enhanced and positively impacted on the preservation of their collections. This reveals that all the university libraries surveyed have preservation and conservation techniques as well as preservation policies.

Constraints against Effective Preservation and Conservation of Library Materials

The constraints against effective preservation and conservation of library materials in the university libraries are presented in Table 9.

Table 9: Constraints against effective preservation and conservation of library materials

\begin{tabular}{|c|c|c|c|c|c|}
\hline Possible constraints & $\begin{array}{l}\text { No } \\
\text { Extent }\end{array}$ & $\begin{array}{l}\text { Little } \\
\text { Extent }\end{array}$ & $\begin{array}{l}\text { Very great } \\
\text { Extent }\end{array}$ & Mean & Std \\
\hline Inadequate funding of the library & $1(6.7)$ & $7(46.7)$ & $7(46.7)$ & 2.60 & 0.14 \\
\hline Lack of competent manpower & $8(53.3)$ & $3(20.0)$ & $3(26.7)$ & 1.93 & 0.15 \\
\hline Lack of preservation and conservation policy & $0(0.0)$ & $0(0.0)$ & $0(0.0)$ & 0.00 & 0.00 \\
\hline Inadequate infrastructure & $2(13.3)$ & $5(33.3)$ & $8(53.3)$ & 2.53 & 0.20 \\
\hline Administrative bottlenecks & $5(33.3)$ & $4(26.7)$ & $6(40.0)$ & 2.27 & 0.19 \\
\hline $\begin{array}{l}\text { Harsh environmental conditions accelerating library materials } \\
\text { depreciation }\end{array}$ & $5(33.3)$ & $3(20.0)$ & $7(46.7)$ & 2.27 & 0.11 \\
\hline $\begin{array}{l}\text { Outdates or non-existent hardware, software and network } \\
\text { connectivity }\end{array}$ & $6(40.0)$ & $5(33.3)$ & $4(26.6)$ & 2.00 & 0.16 \\
\hline Others & $15(100.0)$ & $0(0.00)$ & $0(0.00)$ & 1.00 & 0.08 \\
\hline
\end{tabular}

Source: Field survey August 2007 
The results from the mean and standard deviation values of the parameters in Table 9 show that the greatest constraint facing the libraries is "inadequate funding" $(2.60 \pm 0.14)$. This is followed by "inadequate

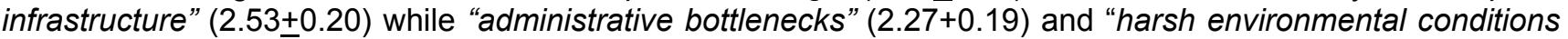
accelerating library materials depreciation" $(2.27+0.11)$ was following in order of constraints. However, "lack of competent manpower" and "lack of preservation and conservation policies" are not seen as constraints. In other words, the university libraries are not faced with policy or human resource problems, but rather, infrastructure and administrative problems in carrying out their preservation and conservation activities. This has revealed that the preservation and conservation policies in these libraries are very effective and they have competent staff handling library activities.

\section{DISCUSSION}

The outcome of the study revealed that the most used patterns and strategies in the preservation and conservation of print and non-print library materials in the university libraries is cleaning and dusting of information materials, while the least used strategy is the use of insecticide and insect repellant. The results also show that the major cause of deterioration of library materials is wear and tear due largely to excessive photocopying of the information materials by users and excessive usage and mishandling of the materials. This finding corroborates Olabode (2005) who stated that wear and tear, excessive light and dust are responsible for the deterioration of library materials.

The findings also revealed that library materials in the university libraries also suffer from high acidity and high temperature levels, although bad shelving and excessive light are the least problems the libraries face. This was finding supports Momoh (1987) who identified the factors responsible for paper deterioration were insects, rainfall, mould/mildew, atmospheric pollutants, excessive heat, low relative humidity and acidity in Nigerian state libraries. Unomah (1988) also asserts that one of the greatest single factors of deterioration of library materials in Nigeria is high temperature and humidity. This has put the information materials especially the print materials in bad shape in these institution's libraries in Nigeria and in the not too distant future, some of these materials may not be available for access by the users.

The combination of high temperature and high humidity hastens the chemical deterioration of materials. These factors also play a major role in the multiplication of some biological agents. High relative humidity provides the moisture necessary to promote harmful chemical reactions in materials and, in combination with high temperature, encourages mould growth and insect activity. Extremely low relative humidity may lead to desiccation and embrittlement of certain materials. This made Williams (2000) suggest that the control of temperature and relative humidity levels should be the concern of any preservation programme. In addition, Varlamoff (2005) while buttressing the effect of biological and environmental agents on library materials submitted that multiple threats menace our heritage and that they may come from the inside and be part of the document itself (acidic paper, for instance, that becomes brittle) or they may have external origins such as fire, water or poor environmental conditions facilitating the growth of mould or the invasion of insects. Varlamoff noted further that too much light, heat, humidity or dryness accelerates the physical decay of the collections.

On the nature and extent of degradation of print library materials, the results show that the highest nature of degradation is books being torn, followed by broken spines, being a result of frequent and careless use of the materials. Vandalism is however the least problem facing the university libraries due to the effective physical security strategies and mechanisms in these libraries. This result is supported by Menges (2006) who submitted that there was no guideline on how to preserve the library materials and this has led to the extent of degradation of library materials. The findings also revealed that cracking and scratching of sound and optical discs is the highest degradation of non-print materials in these institutions due to excessive usage. Although there were changing of colour images, surface blemishes leading to fading of the information in non-print materials, but there was less record of a total loss of data, permanent deformation and distortion of non-print materials.

The findings equally revealed that the degree of ICT utilization in the preservation and conservation activities of the university libraries showed that the use of the digital preservation techniques is refreshing. Also, not all the digital preservation techniques are being used particularly because of lack of awareness. Also, some of the institution libraries' materials were not digitized. This has revealed that institution libraries in Nigeria still have a lot to do in the aspect of ICT adoption and utilization. UNESCO (2003) stated that the high level of electronic document production in the three countries (South Africa, Botswana, and Ethiopia) indicated the need for digital material preservation. This means that digital preservation techniques are not effectively in use in Africa. This is confirms the work by PREMIS (2004) who revealed that most of the digital preservation techniques have not been widely adopted in the community. This implies that if digital preservation is not fully adopted, sooner than later, information materials in these institution libraries will continue to face significant degradation. 
The results further show that most of the university libraries do not duplicate or had no facility to duplicate photographic materials as back up for storage as well as sound discs. The reason is that some of these storage media are outdated and the equipment is no longer available from the market. The most used media in the optical discs is the CD-ROM and the video discs which remain in vogue. As well, floppy disks and cassettes are still very much in use. The results revealed that a lot of work still needs to be done in this area because these institutional libraries will have little or no information materials to fall back on when the original documents are destroyed.

Photocopying as a preservation method was also used in the university libraries but was less common than cleaning and dusting. This contrasts the notion that photocopying is not generally considered as a preservation strategy in Africa as revealed by the Joint International Federation of Library Associations and Institutions/International Council on Archives (IFLA/ICA) Committee on Preservation in Africa (JICPA) survey (Coates, 2000).

Furthermore, more than an average number of the institutional libraries has preservation polices which have really provided direction to library staff in carrying out their collection management responsibilities, and the provisions in the preservation policy are adequately in use and adhered to. This result contrasts with Cloonan (2001) and Menges (2006) submissions that some libraries do not have a preservation policy and with the reports of surveys carried out at the National Archives, National Library and major archives and libraries in Hungary that confirmed that preservation policy formulation was a neglected area (Albrecht-Kunszeri \& Kastaly, 2000). The findings from this study revealed that preservation policy is adequately in use in Nigerian institution libraries.

The greatest constraint against effective preservation and conservation of library materials is inadequate funding. This is supported by Neil (2003) that digital preservation is poorly funded in relation to the scale of the challenge. He noted further that institutional libraries receive little or no additional core funding to address digital preservation. Other constraints that affected the libraries were administrative bottlenecks and harsh environmental conditions that accelerate library materials depreciation. This is confirmed by Feather (1996) that the demand for increase in the temperature in buildings has affected libraries as it does other places. Varlamoff (2005) also advocated the right type of buildings for housing library holdings.

\section{CONCLUSIONS AND POLICY IMPLICATIONS}

This study has shown that preservation and conservation techniques are recognized in the selected Nigerian university libraries, but the techniques are not fully practiced due to some inhibitions notably inadequate finding. Based on these findings, the following policy options and strategies are recommended:

- Institutional libraries need to adopt the digital method of preservation to enable library materials stay a longer time in meeting information needs of the users. Digitization has been widely canvassed as one solution to the problem of information preservation in libraries and archives. However, in most Nigerian libraries where funds are meagre, adopting digital preservation techniques and strategies should be approached with caution. Digitization is tremendously expensive (Conway 2000; L'Homme 1999; Saffady, 1999 (cited in Ngulube, 2003)). For all practical purposes, digitization is costly to implement. The costs are in the form of hardware and software, user training requirements, manpower to sustain the system, converting archival materials to machine-readable form and maintenance. At times, huge digital files can also be expensive to store and difficult to transfer. Many digital technology enthusiasts often ignore these cost implications (Ngulube, 2003). Thus, for the Nigerian university libraries in this study that are established as under-funded, the cost implications of adopting digital preservation techniques may be prohibitive.

- In addition, there should be adequate and trained manpower in the libraries for preservation and conservation programmes and activities to succeed because preservation and conservation activities are specialized and require information professionals who understand the physical and chemical nature of the materials in their library holdings.

- Although, most of the surveyed libraries have preservation policies setting out guidelines for preservation and conservation of library materials, such policies need to be implemented and reviewed from time-to-time to cater for new challenges and emerging technologies.

- The libraries should also be made to provide for issues relating to disaster planning since a preservation plan helps to ensure that limited resources are used consistently and economically. It also helps in raising awareness of libraries' preservation problems as well as the institutionalization of the preservation process and increasing knowledge among staff (Reed-Scott, 2000). 
In is hoped that this study might give Nigerian libraries the strategic direction they require to initiate any preservation measures for the protection of their holdings. No doubt, it will also assist the libraries to understand the physical needs of records and to meet, or extend, nationally and internationally agreed standards for their preservation. Knowledge generated from the study forms an important component in the decision-making process. It is evident that there is very little researched-based information in Nigeria on preservation and conservation of library materials. Thus, suggestions given in the study are likely to inform the decision-making process and the allocation of funds for better preservation activities and programmes. Training and education of library personnel and preservation and conservation practices in Nigerian libraries could be influenced by the results of the study provided the recommendations are pursued with the necessary actions they require.

\section{REFERENCES}

Akotia, P. (2000). Financial Records Management Project: Phase Three. Submitted to the Government of Uganda, 17-28 January. Kampala: DFID: 1-24.

Albrecht-Kunszeri, G. \& Kastaly, B. (2000). Developing preservation training of archive and library staff in Hungary. In de Lusenet, Y. (ed.) Preservation management: between policy and practice. Amsterdam: European Commission on Preservation and Access, pp. 4-13.

Cloonan, M. V. (2001). W(h)ither preservation? Library Quarterly 71(2) 231-242.

Coates, P. R. (2000). JICPA survey of conservation facilities and experts in Africa. Retrieved November 26, 2006. from: http://epa_prema.net/jicpa/survey.htm.

Conway, P. L. (2000). Overview: rationale for digitisation and preservation. In: Sitts, M. K. (ed.) Handbook for digital projects: a management tool for preservation and access. 1st ed. Andover, MA: Northeast Document Conservation Center. Retrieved December 5, 2006 from: http://www.nedcc.org.

ESARBICA. (2002). Minutes of the ESARBICA Executive Board meeting held at the Mountain Inn, Mbabane, Swaziland, 11-13 March 2002.

Feather, J. (1996). Preservation and the Management of Library Collections. Library Association Publishing Ltd.

IFLA-PAC China Centre (2006). Strategic Plan 2006-2008. Retrieved $17^{\text {th }}$ March 2008 from: http://www.nlc.gov.cn/en/services/iflapac_chinacenter/strategem.htm.

Jantz, R. \& Giarlo, M.J (2005). Digital Preservation: Architecture and Technology for Trusted Digital Repositories. D-Lib Magazine. 11 (6). Retrieved August 2, 2008 from: http://www.dlib.org/dlib/june05/jantz/06jantz.html

Katundu, D. R. M. (2001). Preservation challenges for Africa's information systems: the case of electronic records. Information Development 17(3)179-182.

Kemoni, H. N \& Wamukoya, J. (2000). Preparing for the management of electronic records at Moi University, Kenya. African Journal of Library, Archives and Information Science 10(2) 125-138.

Kenney, A. R., McGovern, N. Y., Botticelli, P., Entlich, R., Lagoze, C. \& Payette, S. (2002). Preservation Risk Management for Web Resources, D-Lib Magazine 8(1). Retrieved March 10, 2008 from:

http://www.dlib.org/dlib/january02/kenney/01kenney.html.

Lee, K., Slattery, O., Lu, R., Tang, X., \& McCarry, V. (2002). The State of the Art and Practice in Digital Preservation. Journal of Research of the National Institute of Standards and Technology. 107(1). Retrieved June 25, 2007 from: http://nvl.nist.gov/pub/nistpubs/jrest/107/1/j71/lee.pdf.

L'Homme, C. (1999). Memory of the world. UNESCO Sources. 117, 14-15.

Menges, G. L (2006). Preservation and Conservation of Library Materials. Retrieved March 30, 2007 from: http://www.lib.washington.edu/presevation/preservationsyllabus2006.pdf. 
Momoh, S. T. (1987). State of Preservation and Conservation in Nigerian State Libraries, Nigerian Libraries, 10, (4), 16-22.

Mnjama, N. \& Wamukoya, J. (2004). E-government and e-records management. Paper presented at the SADC Workshop on E-government, Gaborone, Botswana, 14-16 April 2004.

National Library of Australia (2004) Preservation Policy. Retrieved December 10, 2007 from: http://www.nla.gov.au/policy/pres.html.

Neil, B (2003). Study on National Digital Preservation Initiatives. Council on library and Information and Library of Congress. Retrieved August 17, 2007 from: http://www.clir.org/pubs/report/pubs116/content.html.

Ngulube, P. (2001). Guidelines and standards for records management education and training: a model for Anglophone Africa. Records Management Journal 11(3), 155-173.

Ngulube, P. (2002). Preservation reformatting strategies in selected Sub Saharan African archival institutions. African Journal of Library, Archives and Information Science 12(2), 117-132.

Ngulube, P. (2003) Preservation and Access to Public records and Archives in South Africa. Unpublished doctoral thesis submitted to the School of Human and Social Studies, University of Natal, Pietermaritzburg. Retrieved July 18, 2008 from: http://www.infs.ukzn.ac.za/thesispn.pdf

Olabode, F. S. (2005). Preservation and Conservation of Library Materials: A Case Study of Library, Archival and Information Studies (LARIS) Library. Unpublished master's degree dissertation submitted to the Department of Library, Archival and Information Studies, University of Ibadan, Nigeria.

Popoola, S.O. (2003). Preservation and Conservation of Information Resources. University of Ibadan, Nigeria: Distance Learning Centre.

PREMIS (2004). Implementing Preservation Repositories for Digital Materials: Current Practice and Emerging Trends in the Cultural Heritage Community. Retrieved June 15, 2007 from:

http://www.oclc.org/research/projects/pmwg/surveyreport.pdf.

Reed-Scott, J. (2000). Planning for preservation in libraries. In: Banks, P. N \& Pilette, R. (Eds). Preservation: issues and planning. Chicago: American Library Association, pp.82-96.

Rothenberg, J. (1995). Ensuring the longevity of digital documents. Scientific American 272 (1) 24-29.

UNESCO (2003). Digital Preservation Research Project. Retrieved July 8, 2007 from: http://aboutdisa.ukzn.ac.za/workshops/UNESCODigPres/final\%20report\%20\%20Digital\%20Pres ervation\%20comparative\%20study.pdf.

UNESCO (2000). Safeguarding our documentary heritage. Retrieved May 12, 2007 from: http://webworld.unesco.org/

Unomah, J. I. (1988). Deterioration and Restoration of Library Materials: The Nigerian Situation. Nigerbiblios, 13(2) $10-15$

Varlamoff, M. (2005) The first step in preservation: building the right building. Paper presented at the World Library and Information Congress: 71st IFLA General Conference and Council "Libraries - A voyage of discovery" August 14th - 18th 2005, Oslo, Norway. Retrieved September 6, 2008 from: http:/lwww.ifla.org/IV/ifla71/papers/100e-Varlamoff.pdf.

Wamukoya, J. \& Mutula, S. M. (2005, December). E-records Managament and Governance in East and Southern Africa. Malaysian Journal of Library \& Information Science, 10(2) 67-83

Waugh, A., Wilkinson, R., Hills, B., Dell'oro, J. (2000). Preserving digital information forever, In Proceedings of the fifth ACM conference on Digital libraries, p.175-184, San Antonio, Texas, USA.

Williams, S. R. (2000). Preservation programs in high-use library collections. In: Banks, P. N \& Pilette, R. (Eds). Preservation: issues and planning. Chicago: American Library Association, pp. 28-42. 


\section{QUESTIONNAIRE}

Dear Respondent,

This questionnaire is designed to collect data for a study on "Preservation and Conservation Techniques in Selected University Libraries in Nigeria". I humbly request your cooperation in completing the questionnaire. All responses will be used only for academic purpose. Thank you for your anticipated cooperation.

Researcher

\section{SECTION A: LIBRARY'S DEMOGRAPHIC INFORMATION}

1. Name of Library:

2. Institution of Library:

3. Year of Establishment:

4. Category of Institution: Federal [ ] State[ ] Private[ ]

\section{SECTION B: NATURE AND EXTENT OF DEGRADATION OF INFORMATION MATERIALS}

Please respond to the following items by a tick $(\sqrt{ })$ in front of the response that depicts your opinion.

5. What is the nature and to what extent have your library materials degraded?

\begin{tabular}{|c|c|c|c|c|c|}
\hline & $\begin{array}{l}\text { NATURE OF DEGRADATION OF PRINT LIBRARY } \\
\text { MATERIALS }\end{array}$ & $\begin{array}{c}\text { No } \\
\text { Extent } \\
0\end{array}$ & $\begin{array}{c}\text { Little } \\
\text { Extent } \\
1\end{array}$ & $\begin{array}{c}\text { Moderate } \\
\text { Extent } \\
2\end{array}$ & $\begin{array}{c}\text { Very } \\
\text { Great } \\
\text { Extent } \\
3\end{array}$ \\
\hline a. & Mutilation of library materials & & & & \\
\hline b. & Vandalization of library materials & & & & \\
\hline c. & Brittle library materials & & & & \\
\hline d. & Broken spine of library materials & & & & \\
\hline e. & Books becoming torn & & & & \\
\hline \multirow[t]{2}{*}{ f. } & Other (Please specify) - & & & & \\
\hline & $\begin{array}{c}\text { NATURE OF DEGRADATION OF NON-PRINT } \\
\text { LIBRARY MATERIALS }\end{array}$ & & & & \\
\hline a. & $\begin{array}{l}\text { Changing of colour of image in photographic } \\
\text { materials }\end{array}$ & & & & \\
\hline b. & $\begin{array}{l}\text { Surface blemishes leading to fading of the image in } \\
\text { photographic materials }\end{array}$ & & & & \\
\hline c. & Permanent deformation of sound discs & & & & \\
\hline d. & Fungi on discs surfaces & & & & \\
\hline e. & Cracking and scratching of sound and optical discs & & & & \\
\hline f. & Poor playback quality of sound discs & & & & \\
\hline g. & Distortion of sound quality on magnetic media & & & & \\
\hline h. & Loss of data on magnetic media & & & & \\
\hline i. & Other (Please specify) -- & & & & \\
\hline
\end{tabular}


6. Which of the following are the causes of deterioration of library materials, and to what extent?

\begin{tabular}{|l|l|c|c|c|c|}
\hline \multicolumn{1}{|c|}{ PRINT MATERIALS } & $\begin{array}{c}\text { No } \\
\text { Extent } \\
\mathbf{0}\end{array}$ & $\begin{array}{c}\text { Little } \\
\text { Extent } \\
\mathbf{1}\end{array}$ & $\begin{array}{c}\text { Moderate } \\
\text { Extent } \\
\mathbf{2}\end{array}$ & $\begin{array}{c}\text { Very Great } \\
\text { Extent } \\
\mathbf{3}\end{array}$ \\
\hline a. & High acidity levels & & & & \\
\hline b. & Wear and tear due to excessive photocopying & & & & \\
\hline c. & Air pollution & & & & \\
\hline d. & High temperature levels & & & & \\
\hline e. & Relative humidity & & & & \\
\hline f. & Excessive light & & & & \\
\hline g. & Dusts and particulate matters & & & \\
\hline h. & $\begin{array}{l}\text { Biological agents (e.g. termite, cockroaches, } \\
\text { spiders, rodents etc) }\end{array}$ & & & \\
\hline i. & Bad Shelving & & & \\
\hline j. & $\begin{array}{l}\text { Other (Please specify) ------------------------------ } \\
\text { - NON-PRINT MATERIALS }\end{array}$ & & & \\
\hline & \multicolumn{1}{|c|}{} & & & \\
\hline a. & Oxidation & & & \\
\hline b. & Magnetism & & & \\
\hline c. & High humidity and heat & & & \\
\hline d. & Moisture & & & \\
\hline e. & Dust & & & \\
\hline f. & Biological agents (e.g. termites) & & & \\
\hline g. & Atmospheric pollutants & & & \\
\hline h. & Excessive light & & & \\
\hline i. & Other (Please specify) ----------------------------- & & & \\
\hline
\end{tabular}

\section{SECTION C: THIS SECTION AIMS AT COLLECTING DATA ON THE GENERAL USE OF PRESERVATION AND CONSERVATION TECHNIQUES IN YOUR LIBRARY}

7. Do you use preservation and conservation techniques in your library? [ ] Yes [ ] No

8. If yes to No. 7, how long have you been using the techniques in your library?
[ ] $1-5 \mathrm{yrs}$
] $6-10 \mathrm{yrs}$
] $11-15$ yrs
$16-20$ yrs
21 yrs and above

9. Which of these techniques below does your library adopted to preserve and conserve library materials, and how often? (Tick as many as applicable)

\begin{tabular}{|c|l|l|l|l|}
\hline & PRESERVATION AND CONSERVATION TECHNIQUES & Very Often & Occasionally & Never \\
\hline a. & Lamination & & & \\
\hline b. & Microfilming & & & \\
\hline c. & Deacidification & & & \\
\hline d. & Binding & & & \\
\hline e. & Encapsulation & & \\
\hline f. & Cleaning and dusting of library materials & & \\
\hline g. & Photocopying & & \\
\hline h. & Shelving library materials to allow for free flow of air & & \\
\hline i. & Installing air-conditioners in your library & & \\
\hline j. & $\begin{array}{l}\text { Provision of adequate security systems to prevent theft, } \\
\text { mutilation and defacing of paper-based materials }\end{array}$ & & \\
\hline k. & $\begin{array}{l}\text { Use of insecticide and insect repellant for library materials' } \\
\text { preservation }\end{array}$ & & & \\
\hline I. & Other (Please specify) ---------------------------------------- & & & \\
\hline
\end{tabular}


10. Are the information in your non-print materials transferred to other storage media for duplication? [ ] Yes [ ] No

11. If yes to Question No 10, which of the following storage media do you use for duplication? (Tick as many as applicable)

\begin{tabular}{|l|l|l|l|}
\hline & \multicolumn{1}{|c|}{ STORAGE MEDIA } & Yes & No \\
\hline & Photographic Materials & & \\
\hline a. & Motion picture & & \\
\hline b. & Film & & \\
\hline c. & Microforms & & \\
\hline & Optical Discs & & \\
\hline a. & CD-ROM & & \\
\hline b. & Optical Character Recognition (OCR) & & \\
\hline c. & Magnetic Ink Character Recognition (MICR) & & \\
\hline d. & Bar pens & & \\
\hline e. & Video discs & & \\
\hline & Sound Discs & & \\
\hline a. & Microgroove discs & & \\
\hline b. & Shellac disks & & \\
\hline c. & Vinyl discs & & \\
\hline & Magnetic Media & & \\
\hline a. & Cassettes & & \\
\hline b. & Floppy discs & & \\
\hline c. & Magnetic tapes & & \\
\hline d. & Cellulose acetate & & \\
\hline e. & Mylar & & \\
\hline
\end{tabular}

\section{SECTION D: ICT UTILIZATION IN PRESERVATION AND CONSERVATION}

12. Does your library have digital resources in its collections?

$$
\text { [ ] Yes [ ] No }
$$

13. Which of the following digital preservation techniques do you use in your library and how often? (Tick

Many as applicable)

\begin{tabular}{|l|l|l|l|l|}
\hline \multicolumn{1}{|c|}{ DIGITAL PRESERVATION TECHNIQUES } & $\begin{array}{c}\text { Very } \\
\text { Often }\end{array}$ & Occasionally & Never \\
\hline a. & Refreshing (Periodic copying from one physical medium to another) & & & \\
\hline b. & $\begin{array}{l}\text { Technology preservation (Replicating any old configuration of } \\
\text { hardware and software) }\end{array}$ & $\begin{array}{l}\text { (Tigration (Transfer of digital materials from one generation of } \\
\text { computer technology to a subsequent generation) }\end{array}$ & & \\
\hline c. & Emulation (Preserving the original application program) & & \\
\hline e. & $\begin{array}{l}\text { Encapsulation (Creating the original application that was used to } \\
\text { create or access the digital object on future computer platforms) }\end{array}$ & & \\
\hline f. & Microfilming & & & \\
\hline h. & None of the above & & & \\
\hline i. & Other (Please specify) ------------------------------------------------- & & \\
\hline
\end{tabular}

14. For how long has this technique(s) in No. 13 been in use in your library?
a) Less than $1 \mathrm{yr}$
b) $1-5 \mathrm{yrs}$
c) $6-10 \mathrm{yrs}$
d) $11 \mathrm{yrs}$ and above 


\section{SECTION E: PRESERVATION AND CONSERVATION POLICIES}

15. Does your library have a preservation policy? [ ] Yes [ ] No

16. If yes to No.15, is the preservation policy in use in your library? [ ] Yes [ ] No

17. If yes to No. 16, how long have the policy been in existence in your library?

[ ] Less than $1 \mathrm{yr}$ [ ] 1-5 yrs [ ] 6 -10 yrs [ ] 11yrs and above

18. Has the policy provided direction to library staff in carrying out their collection management responsibilities relating to preservation?

$$
\text { [ ] Yes [ ] No }
$$

19. Does the preservation policy provide guidelines for the following? (Tick as many as applicable)

\begin{tabular}{|l|l|c|c|}
\hline & PRESERVATION POLICY PROVISIONS & Yes & No \\
\hline a. & Security of library materials & & \\
\hline b. & Disaster recovery procedure & & \\
\hline c. & Use of library materials & & \\
\hline d. & Handling of library materials & & \\
\hline e. & Training of staff on preservation of library materials & & \\
\hline f. & Restoration of degradated library materials & & \\
\hline g. & Other (Please specify) ------------------------------------------------- & & \\
\hline
\end{tabular}

20. Has the policy enhanced preservation positively?

[ ] Yes [ ] No

\section{SECTION F: CONSTRAINTS AGAINST EFFECTIVE PRESERVATION AND CONSERVATION OF LIBRARY MATERIALS IN YOUR LIBRARY}

21. Which of the following constrain effective preservation and conservation of library materials?

\begin{tabular}{|l|l|c|c|c|c|}
\hline \multicolumn{1}{|c|}{ POSSIBLE CONSTRAINTS } & $\begin{array}{c}\text { No } \\
\text { Extent } \\
\mathbf{0}\end{array}$ & $\begin{array}{c}\text { Little } \\
\text { Extent } \\
\mathbf{1}\end{array}$ & $\begin{array}{c}\text { Average } \\
\text { Extent } \\
\mathbf{2}\end{array}$ & $\begin{array}{c}\text { Great } \\
\text { Extent } \\
\mathbf{3}\end{array}$ \\
\hline a. & Inadequate funding of the library & & & & \\
\hline b. & $\begin{array}{l}\text { Lack of competent manpower in preservation and } \\
\text { conservation }\end{array}$ & & & & \\
\hline c. & Lack of preservation and conservation policy & & & & \\
\hline d. & Inadequate infrastructure & & & \\
\hline e. & Administrative bottlenecks & & & \\
\hline f. & $\begin{array}{l}\text { Harsh environmental conditions accelerating library } \\
\text { materials depreciation }\end{array}$ & & & \\
\hline g. & $\begin{array}{l}\text { Outdated or non-existent hardware, software and network } \\
\text { connectivity }\end{array}$ & & & & \\
\hline h. & Other (Please specify) ------------------------------------ & & & & \\
\hline
\end{tabular}

END OF QUESTIONNAIRE

Thank you for sparing your time to fill out this questionnaire 